\title{
ISO Capabilities in Enhancing the Quality of Teaching \& Learning in Malaysian Polytechnic
}

\section{Norsaadah Sapon}

To Link this Article: http://dx.doi.org/10.6007/IJARBSS/v11-i1/9010

DOI:10.6007/IJARBSS/v11-i1/9010

Received: 01 December 2020, Revised: 06 January 2021, Accepted: 16 January 2021

Published Online: 26 January 2021

In-Text Citation: (Sapon, 2021)

To Cite this Article: Sapon, N. (2021). ISO Capabilities in Enhancing the Quality of Teaching \& Learning in Malaysian Polytechnic. International Journal of Academic Research in Business and Social Sciences, 11(1), 877-889.

Copyright: (c) 2021 The Author(s)

Published by Human Resource Management Academic Research Society (www.hrmars.com)

This article is published under the Creative Commons Attribution (CC BY 4.0) license. Anyone may reproduce, distribute, translate and create derivative works of this article (for both commercial and non-commercial purposes), subject to full attribution to the original publication and authors. The full terms of this license may be seen at: http://creativecommons.org/licences/by/4.0/legalcode

Vol. 11, No. 1, 2021, Pg. 877 - 889

Full Terms \& Conditions of access and use can be found at http://hrmars.com/index.php/pages/detail/publication-ethics 


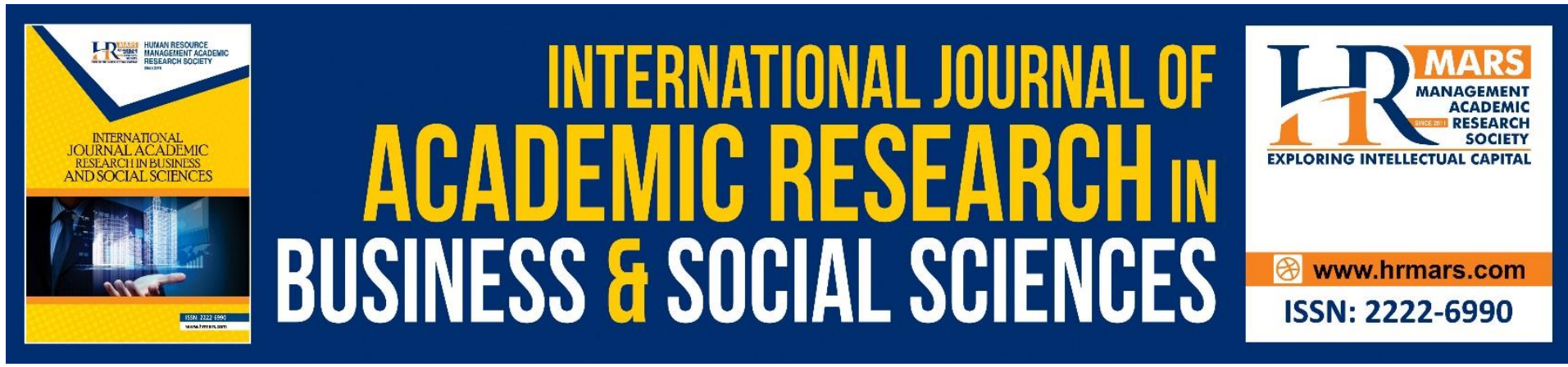

\title{
ISO Capabilities in Enhancing the Quality of Teaching \& Learning in Malaysian Polytechnic
}

\author{
Norsaadah Sapon \\ Politeknik Kuching Sarawak (PKS), Malaysia.
}

\begin{abstract}
International Organization for Standardization (ISO) is to produce quality management procedures and involves the responsibility of lecturers to implement teaching and learning based on the procedures outlined by the organization of the educational institution. This study will be conducted to know the perception of lecturers in Politeknik Kuching Sarawak (PKS) on the importance of ISO and ISO's ability to improve the quality of Teaching and Learning (T\&L) based on factors such as teaching preparation, teaching delivery, teaching content, teaching aids (ABBM), T\&L Documents and lecturer's personality. This study will use quantitative design, including descriptive statistical tests based on the questionnaire. The population of this study was comprised of the entire PKS' lecturers. The expected result is the lecturers evaluate ISO as an important factor in improving the quality of T\&L.
\end{abstract}

Keywords: International Organization for Standardization, Teaching \& Learning, Politeknik Kuching Sarawak, Quality Improvement, Education.

\section{Introduction}

ISO is an abbreviation for International Organization for Standardization. It is an associate or standards body that developed the standards in Geneva, Switzerland in 1964 (Othman, 2000), which aimed to establish a quality management system in the management of an organization. In Malaysia, the Malaysian Institute of Standards and Industrial Research (SIRIM) is the governing body of this ISO series (Zubir, 2003).

Politeknik Kuching Sarawak (PKS) has obtained the ISO certification in 18 Mei 2012. The main purpose of PKS is to produce holistic and competent TVET graduates who are capable of contributing to national development (PKS Website).

The quality was the main focus at the Institute of Higher Learning (IPTA), especially involving customer requirements, continuous improvement and collaboration within a team (Zulkifli, 2007). PKS has emphasized the quality of Teaching and Learning (T\&L) as well as the productivity of lecturers, the process of self-evaluation or reflection in teaching activities. Teaching and learning (T\&L) process implemented based on ISO guidelines will help to create a competent lecturer in educational institutions. This is because the role of the ISO itself is aimed at producing quality management procedures and indirectly it also involves the 
responsibility of lecturers to undertake teaching and learning based on the procedure outlined by the organization or educational institution (Seman, 2005).

The MS ISO 9001 means that an organization has established a systematic approach to instill quality by ensuring that their products meet customer requirements. This does not mean that the product is conforming to product standards. It means that the products are being produced through processes which have consideration for quality in the aspects set out by the standard.

The quality manual is a key document in the implementation of a quality management system in addition to quality procedures, work instructions and supporting documents (General Administration, Prime Minister's Department). The ISO Quality Management System emphasizes prevention rather than addressing problems as they occur as well as ongoing reviews of critical processes and making corrective and preventative actions.

The importance of quality assurance in the quality of education programs offered by institutions of higher learning in the country should be emphasized in order to ensure capability in making Malaysia a regional education hub (Yasin, 2009). The importance of Academic Quality Assurance in the higher education sector comes from a sense of responsibility. Implemented to ensure quality is in line with its implementation. While the effectiveness of the quality assurance system can be evaluated through quality audits and the quality of this quality depends on its level of implementation (Hager, 1997; Mahony, 1991).

ISO is to produce quality management procedures and involves the responsibility of lecturers to implement teaching and learning based on the procedures outlined by the organization of the educational institution (Seman, 2005). The quality of education refers to the success of an institution in providing an educational environment that enables students to effectively achieve their learning goals and academic standards (Rowley, 1996). Subscribers to an Institute of Higher Education (HEIs) include students, faculty, and support staff. Students are among the major clients of HEls that need attention and they expect fun learning experiences and quality R\&D processes (Tang and Lim, 2002).

\section{Research Objective}

The objectives for this research are to identify lecturers' perceptions of the importance of ISO in enhancing T\&L quality. Research also to know is there any disagreement based on the background of the lecturer. The second objective knows the level of ISO capability to improve the quality $T \& L$ based on the factors that affect $T \& L$. The factors include lesson preparation, delivery of teaching, content of the lesson, ABBM, T\&L documents and lecturer's personality. 


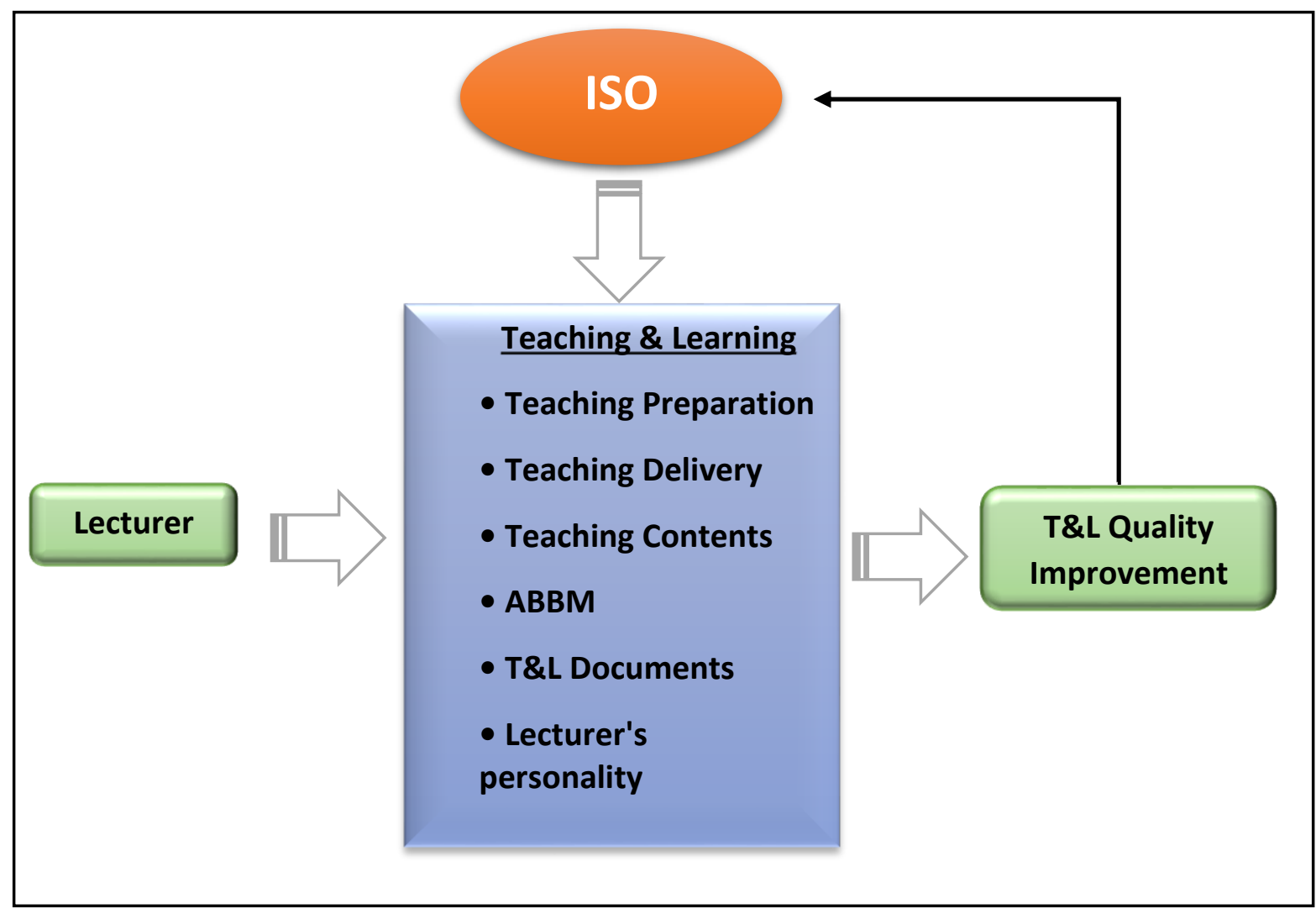

Figure 1. Diagrams of concept framework research

\section{What is Quality}

According to Oakland (1996), quality means meeting needs and reliability. The mean level of quality excellence, adaptation needs, the number of products or services provided the appropriateness of its use and free of damage (Hoyle, 2001). When further defined quality definitions in the context of an audit, it is a process involving the organization, employees within the organization and an audit process involving the preparation of reports. The reports provided should be high level and implemented efficiently and the audit process may be improved from time to time (Auditor General, 2014).

\section{The Importance of Quality in Education}

Quality in education includes standards of learning, teaching effectiveness, management smoothness and job satisfaction among educators and students (Sidin, 1998). According to YB Dato 'Mustapa Mohamed, Minister of Higher Education 2007, to make Malaysia a destination for higher education, public confidence in the country's quality of higher education needs to be constantly enhanced. This proves that quality education is crucial to realizing the country's hope of making Malaysia a regional education hub. Quality in education is strongly associated with the quality of teaching and learning. Therefore, it is important to create a comfortable environment for quality teaching and learning, a more innovative and creative workforce that is technologically, economically and socio-cultural in education (Zulkifli, 2007). 
Quality lecturers are lecturers who can meet the needs of their students and their objectives in terms of academic excellence, good teaching knowledge, teaching certificates and good teaching experience especially in terms of mastery of skills (Zulkifli, 2007). Therefore, organizations and educational institutions need to identify the areas that need to be prioritized to ensure that the quality of education is preserved and maintained. Among the aspects that need to be addressed are institutional culture, planning, institutional development, monitoring and development of academic staff and support (Hin, 2005). The lecturers and educators are the key to the effectiveness and quality of education (Sidin, 1998).

The education in the 21st century concern to prepare for life and work for society (Triling \& Hood, 1999) and the process of forming a knowledgeable society in the education world. Nelson (2006) in his writing on time management for teachers stated that increasing administrative tasks, national curricula, new tests and student work assignments were causing stress among teachers. There is a big question, how can teachers manage time in the face of increasing responsibility after spending five hours or longer. The work of educators is increasing and challenging as education is a priority in a developing country. Teacher workload is increasing as parents and the public have high expectations for teachers to educate their children and often educators are questioned if these expectations are not met.

Quality education is defined as any educational service that meets the needs and expectations of consumers. The users of the national education system are made up of three groups of students and their parents, employers and communities, and the government and the country (Ghani, 1995).

A quality education system will try to satisfy the above three groups of consumers and strive to continuously improve their satisfaction. It will also serve its clients (officers, teachers, lecturers and support staff) appropriately to enable them to make an optimal contribution to the achievement of the organization's goals (Ghani, 1995).

\section{Introduction to ISO}

The International Organization for Standard (ISO) was established in 1946 with headquarters in Geneva, Switzerland, a worldwide organization of 92 countries (Maizul, 2004). According to Puri (1995), the objective of ISO is to establish a standard that is referred to and applied in trade, communication and manufacturing activities. The existence of these standards connects the global community without which it is difficult to conduct life and economic activities. The ISO is actually derived from a Greek word isos meaning equal, homogeneous, and uniform.

A series of international standards or standards for quality systems used as requirements or requirements as well as recommendations for designing and evaluating management systems that guide staff in the performance of their work (Public Administration Development Circular, 1992). Management System Standards provide a model for organizations to follow in creating and operating a management system that emphasizes the ability of organizations to ensure processes or activities to produce products or services that are always in control and quality (Adnan, 2004). 
The ISO adopted in Malaysia as MS ISO 9001 is a written standard and quality management system that sets out the requirements to be complied with. Obviously MS ISO 9001 can be defined as a written standard that sets and explains the basic elements of a quality system that ensures that the service provided meets the customer's requirements. ISO 9001: 2015 refers to an international standard based quality management system based on the version of 2015 as described in the Guidelines for Implementing MS ISO 9001: 2015 in the Public Service (PKPA, 1992).

There are some benefits of MS ISO 9001: 2015. There are:

- QMS will help you to better manage your business to meet customer requirements. This will result in better products, better customer service, satisfied customer and repeat orders

- With proper implementation of the systems, your business will become more efficient and productive thus will reduce errors and rework, reduce operation cost, time and use of resources

- The systems promote continual improvement, which will provide your business with the competitive edge to compete in the market place and for those who have succeeded, to become more successful and resilient

- The systems also look into the needs of your human resource which will also increase staff morale and commitment

- Complying to standards provide you with the accolades for competitive edge

- All of the above will increase profitability

\section{The Implementation of ISO}

There are several steps in the implementation of ISO 9001:

\section{i) Get Training}

All members of the organization should be exposed to the requirements of the MS ISO 9001: 2015 standard. Implementing teams must be established and given skills training to ensure that the implementation of MS ISO 9001: 2015 is smooth and orderly. The members must attend the training, skills as well as Internal Quality Audit training and Management Representative Seminars.

ii) Carry out the gap analysis

Agencies need to carry out a gap analysis comparing existing systems with MS ISO 9001: 2015 requirements. Through this analysis, agencies will be able to identify systems that have or do not adhere to standards and can identify areas that need improvement in order to create an efficient and effective Quality Management System.

iii) Providing MS ISO 9001: 2015 documents

Documentation is one of the methods that controls the processes in the organization and ensures that these processes are uniformly implemented by all members of the organization. The MS ISO 9001: 2015 documentation structure consists of Quality Manuals, Quality Procedures and Work Instructions as well as supporting documents such as forms, records, circulars and other relevant reference documents. 
iv) Conduct an internal audit

Agencies need to identify groups of officers to conduct Internal Quality Audit. They need to be given training that enables them to perform the audit work based on the MS ISO 9001: 2015 standard.

v) Implement the MS ISO 9001: 2015 quality system

Upon passing the Document Audit, the agency will need to implement the Quality Management System as documented. To qualify for an agency applying for a Compliance Audit, the agency must conduct at least one Internal Audit and one Management Review. The purpose of Internal Audit is to evaluate the effectiveness of the existing Quality Management System, to identify existing weaknesses and to take corrective action.

\section{vi) Apply for certification}

The Certification Body must be appointed by the agency to conduct a Compliance Audit on the Quality Management System implemented. All agencies must take corrective action on the findings of the Compliance Audit team. Agencies that have passed the Compliance Audit will be required to receive the MS ISO 9001: 2000 Certificate.

$$
\text { (PKPA, 1992). }
$$

An organization can function effectively if all organizational processes and activities are managed and coordinated efficiently to deliver the services that the organization provides to its customers. The approach of this process can be illustrated through Figure 2 .

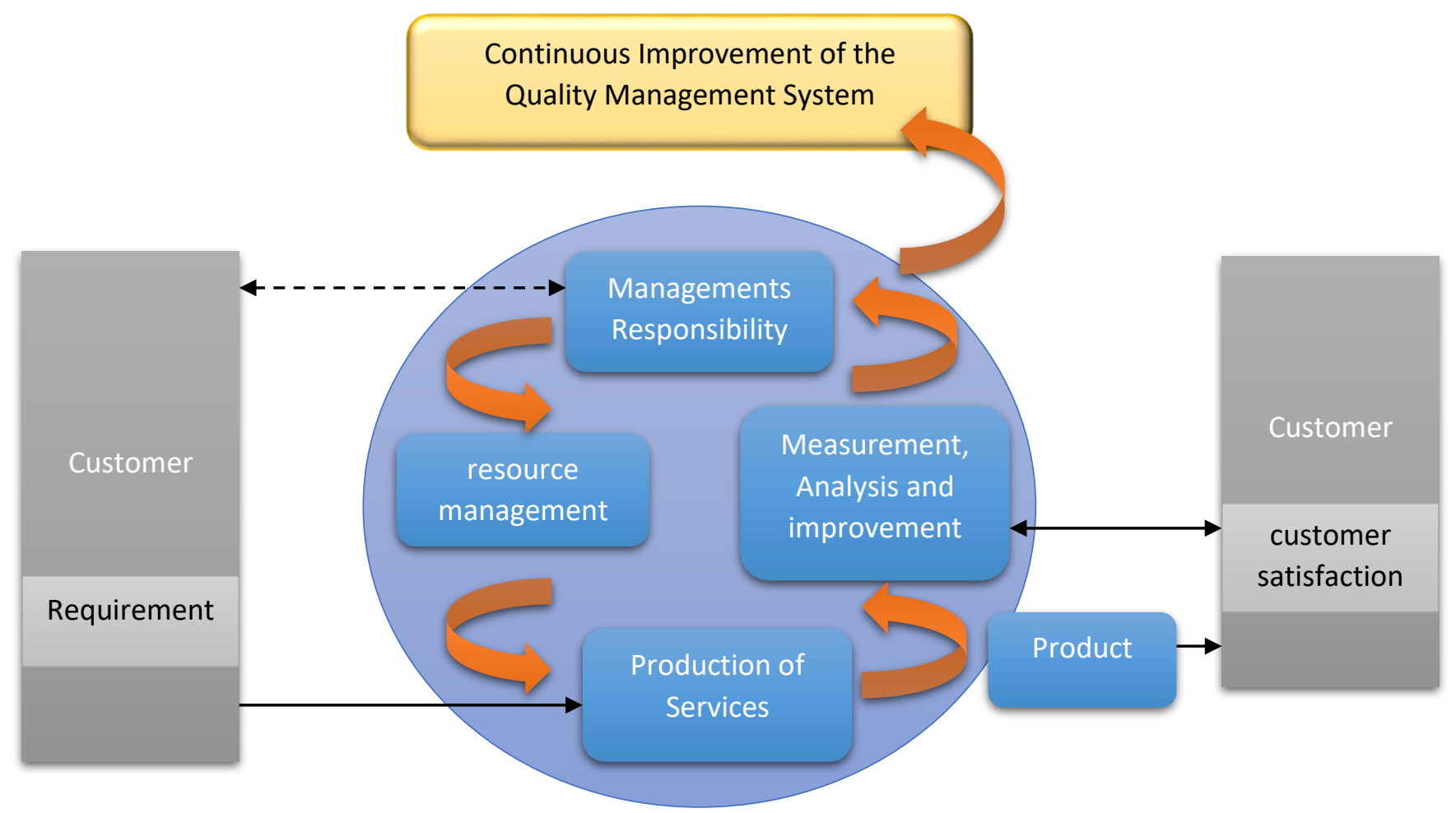

Figure 2. Diagrams of Quality Management System Model Based on Process Approach 
SIRIM QAS International has been recognized by the Department of Standards Malaysia (DSM) and the United Kingdom Services (UKAS) for its Quality System Management Certification service. This DSM certification includes ISO 9000 certification while UKAS includes both ISO 9000 certification and QS-9000 certification. Every company that has obtained an ISO certification will use the certification mark referenced in Figure 3.

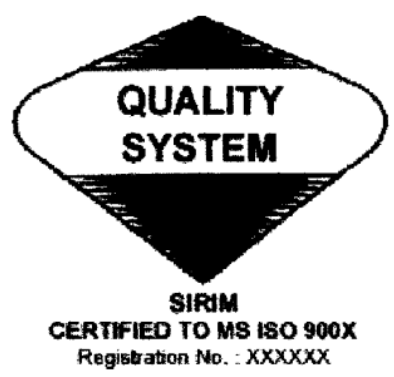

Figure 3. Diagrams of Certification Marks

\section{Application of ISO 9000 in Education}

The current ISO 9000 series poses many problems for education as it was originally required for enterprise management. It is therefore essential that the ISO series translated in the context of education be easily understood by the field of education. The Problems are if measurements made by the production of the product and the product are difficult to translate in education provision. This is because in the context of education products are defined as students (Maizul, 2004). However, according to Sallis (2002), ISO 9000: 2000 is about processes and more in management services and for strengthening education.

ISO 9001: 2015 is based on eight principles that could be adopted by the management team in improving education. The principles are:

i. Focus on customers in the context of education; customers are students, parents, prospective employers or other educational institutions.

ii. Leadership is the ability of a leader to strengthen the mission and goals that are the key to an institution's capabilities. Emphasis on leadership aspects has been proven in studies to be a catalyst for quality improvement in institutions.

iii. Employee engagement is important because an organization needs staff to be able to use all their energy to succeed. Without the involvement of the teaching staff and the technical staff of the educational institution will not function properly. Planning for the needs of staff and making sure their talent is fully utilized is the key to success.

iv. Process approach is related to the efficiency and effectiveness that is the core of the organization and its importance in implementation through a systematic approach to management. Systematic management of the teaching and learning process is indispensable in the principles of process.

v. The management system approach also has a link between the process and the process of achieving the best results. It aims at ensuring a clear system and setting goals and objectives. 
With clear guidelines for excellence and ensuring that the management process achieves its goals, it is the key to education management.

vi. Improvement is the goal of all quality systems. This is to ensure that employees have the training and skills needed for improvement and to ensure an overall organizational approach to performance improvement. Schools and educational institutions also need improvement. One of the key improvements is the importance of staff training and development as well as the need to validate a systematic approach to staff development and adequate investment in training.

vii. The factual approach to decision-making requires decisions to be made based on information and data. The data obtained must ensure that it is true and that the decision made is informed. Students' data and their achievements and related things gained through the educational process are very important in making good decisions in education.

viii. Good relationships with suppliers are also important because organizations that have good relationships with suppliers can give benefit at both sides. It involves open communication, collaboration and skill sharing. Relationships between schools and higher education institutions need to be intertwined in the education system. Relationships with local communities are also important in education.

(Sallis, 2002)

\section{Quality of Teaching and Learning}

Teaching is an assignment and activity that is shared by the teacher and his or her students. Learning is a process of acquiring knowledge or skills. According to Khamis (2006), teaching is an activity or process related to the dissemination of certain knowledge or skills. It covers such things as planning, management, delivery, mentoring and assessment activities, aimed at disseminating knowledge or skills to students effectively (Sang, 2004). The quality of teaching and learning can be enhanced if aspects of planning, implementation, delivery, evaluation and feedback are emphasized. According to Meng (1997), effective teaching involves a number of procedures which include the use of appropriate teaching and learning strategies, good time allocation by teachers, content ranking to facilitate student understanding, effective use of resources and good classroom management.

Weaknesses and inadequacies in teaching by teachers will erode a student's interest in the teaching process.

\section{Research Methodology}

This study will use quantitative design, including descriptive statistical tests based on the questionnaire. According to Ghafar (2003), quantitative studies are a form of research through questionnaires. The results of this study are in the form of figures that can be measured and analyzed using specific methods. Quantitative study is the collection of data on a scale representing values and degrees. In this study, the data will be obtained using the questionnaire using only numbers that have been compiled in scale.

Before a study can be conducted, the population of the study needs to be identified first. Determining the population of a study is important in the research process. Population determines which areas of study to study and which areas of concern to study. Population is 
an observable object that has similar characteristics or characteristics that can be measured (Konting, 2000). The population of this study was comprised of the entire Kuching Sarawak Polytechnic (PKS) lecturer. The number of lecturers in the PKS is 240 . The entire population is 280 lecturers.

Samples are a small fraction of the population and the source for data. In one study, researchers were unable to use all members of the population. The researcher will then choose the population representative of the sample (Ghafar, 2003). Samples for this study will be selected at random using the "Determining sample size for research" table by Krejcie \& Morgan (1970). Respondents should return the completed questionnaire form to the researcher. According to Ghafar (2003), the minimum percentage for a sample of a study is 10 percent to 30 percent. In this study, the sampling design used was a random randomized design. It is the process of extracting elements of a group that forms a population (Khalid, 2003).

The research intents to be used are questionnaire forms. This form is distributed to randomly selected respondents. Konting (2000) argues that the use of questionnaires is more practical and effective in studies of large populations. Validity and reliability values of the study instrument were tested using the Cronbach's alpha method. Questionnaires will be developed based on the research questions. The use of questionnaire form is able to collect detailed, organized and standardized data. This is because the use of questionnaires is easy to administer and can save energy, time, mind and money during the data collection process (Johari, 2003). The questionnaire is divided into three sections:

i. Part A - respondents' demographics (age, gender, long service as lecturer, academic qualification, educational attainment qualification)

ii. Part B - Lecturer's views on ISO capabilities.

iii. Part C - ISO capabilities for improving the quality of T\&L.

The questions in Section A contain various answers. The answer choice is based on the answer code that will be provided. Questions in Parts B and C will use the Likert Scale. According to Konting (2000), this Likert Scale is used to facilitate data collection. The researcher selected the five Likert scale as stated by Sekaran (2003) to ensure that it measured the views and perceptions given by the lecturers on the items presented in Table 1. Numbers 5, 4, 3, 2 and 1 are the coefficients according to Likert Scale scores as shown in Table 1.

Table 1. Feedback group for Likert Scale

\begin{tabular}{|c|c|}
\hline Score & Perception \\
\hline $\mathbf{1}$ & Strongly Disagree \\
$\mathbf{2}$ & Disagree \\
$\mathbf{3}$ & Neither Agree Nor Disagree \\
$\mathbf{4}$ & Agree \\
$\mathbf{5}$ & Strongly Agree \\
\hline
\end{tabular}

The data obtained will be recorded, analyzed and summarized in a form that is easy to understand and interpret in the order of quantitative research questions in which each item answers each research question. All data from Sections A, B and C collected will be analyzed by descriptive statistics method to obtain mean, standard deviation and frequency percentage. The mean score is used to assess the perception of the lecturer whether strongly 
agree, agree, not agree, disagree or strongly disagree. The interpretation of the mean score obtained refers to Table 2 below as suggested by Ghafar (2003).

Table 2. Interpretation of Score Min

\begin{tabular}{|c|c|}
\hline Min Score Range & Interpretation of Scores \\
\hline $1.00-1.50$ & Strongly Disagree \\
\hline $1.51-2.50$ & Disagree \\
\hline $2.51-3.50$ & Neither Agree Nor Disagree \\
\hline $3.51-4.50$ & Agree \\
\hline $4.51-5.00$ & Strongly Agree \\
\hline
\end{tabular}

\section{Expected Results}

- Lecturers evaluate ISO as an important factor in improving the quality of T\&L.

- There is no difference in the lecturer's perception of the importance of ISO assessment in improving the quality of T\&L based on background.

- ISO improves the quality of R\&D in all factors.

- Quality manuals need to be improved so that lecturers can better understand the ISO requirements and requirements and can assist in improving the T\&L.

- ISO evaluation is not only for document evaluation but also for corrective action and preventive action to improve the quality of T\&L.

\section{Conclusion}

Based on the findings, it can be concluded that improving the quality of teaching and learning is very important in realizing for Malaysia to become a regional education hub. Implementing ISOs is one of the most important things in every institution of higher learning to ensure that the services provided meet the needs of the customers. Thus, lecturers should bear their responsibility as educators to improve the quality of $T \& L$ and at the same time bear the responsibility of institution to practice ISO practices.

\section{References}

Adnan, M. M. A (2004). Kajian Terhadap Pelaksanaan ISO Di Makmal-Makmal Kolej Universiti Teknologi Tun Hussein Onn (KUiTTHO). Kolej Universiti Teknologi Tun Hussien Onn: Projek Sarjana.

Auditor General. (2014). Pengauditan Sektor Awam Malaysia. Retrieved from https://www.audit.gov.my/images/pdf/2014/Pengauditan/bm\%20pengauditan\%20se ktor\%20awam\%20malaysia\%20sepintas\%20lalu-1_opt.pdf

Ghafar, M. N. A., (2003). Reka Bentuk Tinjauan Soal Selidik Pendidikan. Skudai: Penerbit Universiti Teknologi Malaysia.

Ghani, A. W. A (1995). Pemikiran Awal Tentang Pengurusan Kualiti Menyeluruh dalam Pengurusan Sekolah. Jurnal Pengurusan Dan Kepimpinan Pendidikan. Kementerian Pendidikan Malaysia. Jilid 5. Bilangan 2. 37-43.

Hager, P. (1997). Quality assurance in VET: Review of research. Australian National Training Authority, NCVER, South Australia. 
Hin, W. N. (2005). Implikasi ISO Terhadap Pembangunan Profesional di Kalangan Pensyarah KUiTTHO. Kolej Universiti Teknologi Tun Hussien Onn: Projek Sarjana.

Hoyle, J. H. (1991). Business Process Improvement - The Breakthrough Strategy for Total Quality Productivity and Competitiveness. McGraw Hill Education.

Jabatan Pengajian Tinggi. (2007). 2007 Annual Report. Retrieved from https://www.yumpu.com/id/document/view/29569547/muat-turun-kandunganlaporan-tahunan-2007-jabatan-pengajian-

Jabatan Perdana Menteri. (2002). Garis Panduan Bagi Melaksanakan MS ISO 9000:2000 Dalam Perkhidmatan Awam. Putrajaya: Surat Pekeliling Kemajuan Pentadbiran Awam Bilangan 2 Tahun 2002. Retrieved from http://mylibrary.nuclearmalaysia.gov.my/seal/Record/0000005176

Johari, K. (2003). Penyelidikan Dalam Pendidikan - Konsep \& Prosedur. Petaling Jaya: Pearson Malaysia Sdn Bhd.

Konting, M. M. (2000). Kaedah Penyelidikan Pendidikan. Kuala Lumpur: Dewan Bahasa Dan Pustaka.

Khamis, A. (2006). Interaksi Guru, Pelajar dan Bahan Pengajaran Ke Arah Pengajaran Berkesan. Kolej Universiti Teknologi Tun Hussien Onn: Projek Sarjana.

Krejcie, R. V., \& Morgan, D. W. (1970). Determining Sample Size For Research Activities. Educational And Psychological Measurement 1970, 30, 607-610. Retrieved from https://home.kku.ac.th/sompong/guest_speaker/KrejcieandMorgan_article.pdf

Mahony, D. (1991). Autonomy and the post-Dawkins universities. Education Research and Perspectives, 18(1), 14-24.

Meng, E. A. (1997). Psikologi Pendidikan II. Edisi Kedua. Shah Alam: Penerbit Fajar Bakti Sdn Bhd.

Nelson, I. (2006). Time Management For Teachers. London And New York: Routledge Taylor \& Francis Group.

Oakland, S. J. (1996). Pengurusan Kualiti Menyeluruh. Terjemahan Mohamad Salmi Mohd Sohod. Kuala Lumpur: Dewan Bahasa dan Pustaka. 3-4.

Othman, M. H. (2000). Menjejak Kualiti Menjana Kecemerlangan. Kuala Lumpur: Dewan Bahasa dan Pustaka.

PKPA - Pekeliling Kemajuan Pentadbiran Awam. (1992). Panduan Pengurusan Kualiti Menyeluruh (TQM) Bagi Perkhidmatan Awam. Pekeliling Kemajuan Pentadbiran Awam Bil.1/1992. 40-43.

Rowley, J. (1996). Motivation and academic staff in higher education. Quality Assurance in Education, 4, 11-16. doi:10.1108/09684889610125814

Sallis, E. (2002). Total Quality Management in Education. 3rd ed. London: Kogan Page Press Limited.

Sang, M. S. (2004). IImu Pendidikan untuk KPLI (Kursus Perguruan Lepasan ljazah). Siri Pendidikan Perguruan. 3rd ed. Subang Jaya: Kumpulan Budiman Sdn Bhd.

Sekaran, U. (2003). Research Method for Business: A Skill - Building Approach. 4th Ed. New York: John Wiley \& Sons, Inc. 197,307.

Seman, N. (2005). Kesan ISO 9000 Terhadap Kompetensi Pensyarah Politeknik. Kolej Universiti Teknologi Tun Hussien Onn: Projek Sarjana.

Sidin, R. (1998). Pendidikan dalam Pemikiran. Shah Alam: Penerbit Fajar Bakti Sdn. Bhd. 28, 214. 
Tang, S. M., \& Lim, K. T. (2002). Hubungan antara kualiti pengajaran dan pembelajaran dengan kepuasan pelajar: satu tinjauan. Utara Management Review, 3 (1). pp. 67-85. ISSN 15117170.

Triling, B., \& Hood, P. (1999). Learning Technology and Education Reform in the Knowledge Age or "We're Wired, Webbed, and Windowed, Now What?". Educational Technology. 1. 5-18.

Yasin, K. (2009). MQA Bertanggungjawab Memantau Mutu Program Ditawarkan Institusi Pengajian Tinggi. Retrieved from http://psasir.upm.edu.my/id/eprint/4520/1/0758.pdf.

Zubir, R. A. (2003). Program Sehari Seminar Kesedaran MS ISO 9000. Bukit Kiara: Unit ISO, Program Kualiti INTAN.

Zulkifli, A. Z. (2007). Implikasi ISO Terhadap Pengurusan Masa Kendiri Pensyarah Di UTHM. Universiti Tun Hussein Onn Malaysia: Projek Sarjana. 